\title{
Erratum
}

\section{MicroRNA-587 antagonizes 5-FU-induced apoptosis and confers drug resistance by regulating PPP2R1B expression in colorectal cancer}

\author{
Y Zhang, G Talmon and J Wang
}

Cell Death and Disease (2016) 7, e2525; doi:10.1038/cddis.2016.450; published online 22 December 2016

Correction to: Cell Death and Disease 2015; 6: e1845. doi: 10.1038/cddis.2015.200

Since the publication of this paper the author has noticed an error in the author list, specifically that Dr. Yang Zhang is abbreviated incorrectly. The correct author list is:
Yang Zhang ${ }^{1}$, G Talmon ${ }^{2}$ and J Wang ${ }^{3}$

The publisher would like to apologise for any inconvenience caused. 